\title{
Synthesis of Methyl Esters of AF-Toxin IIa and IIc, Toxins to Japanese White Pear Produced by Alternaria alternata Strawberry Pathotype
}

\author{
Hiroshi Irie,* Takao Kitagawa, Masaaki Miyashita, and Yong Zhang \\ Faculty of Pharmaceutical Sciences, Nagasaki University, Bunkyo-machi 1-14, Nagasaki 852, Japan. Received May 2, 1991
}

\begin{abstract}
Methyl esters of AF-toxin IIa and IIc, toxic compounds to Japanese white pear produced by Alternaria alternata strawberry pathotype, were synthesized as the optically active forms starting from vitamin $C$ as a chiral material.

Keywords AF-toxin; host-specific toxin; plant pathology; isoleucine; Mitsunobu reaction; $\alpha$-hydroxy-2-methylpentanoic acid; Wadsworth-Emmons reaction; esterification
\end{abstract}

The fungi Alternaria alternata strawberry pathotype produce several kinds of compounds named AF-toxin, which are toxic not only to the host plant but also to Japanese white pear. Some of them were isolated in pure forms and the structures were elucidated by Nakatsuka et al. ${ }^{1)}$ AF-Toxins are closely related structurally to AK-toxins ${ }^{2)}$ in the $\mathrm{C}-11$ trienoic acid moiety. Because of their biological activity and their novel structures, there have been several reports ${ }^{3-5)}$ concerning the synthesis of these toxins and their esters. We also reported the synthesis of the methyl ester (1) of AK-toxin II and pointed out that the stereochemistries of two chiral centers in the C-11 trienoic acid moiety played an important role in the toxicity-structure relationship. ${ }^{6)}$ As a continuation of our synthetic work on the toxins, we report here the synthesis of the methyl esters (3 and 2) of AF-toxin IIa and IIc, which differ from each other in the double bond geometry of the trienoic acid moiety. When we initially examined the synthesis of AF-toxins, the exact stereochemistry of the $\alpha$-hydroxy- $\beta$-methylpentanoic acid moiety in the toxins had not been firmly elucidated. ${ }^{7)}$ Therefore, preparation of the diastereoisomeric acids (threo and erythro-forms) in optically active forms was required to complete the synthesis of these toxin methyl esters.

Treatment of isoleucine (4) with sodium nitrite in acetic acid gave the $\alpha$-acetoxy- $\beta$-methylpentanoic acid (5) as a result of retention of the configuration of an $\alpha$-amino group. ${ }^{8)}$ Esterification of the acid (5) with benzyl alcohol in benzene in the presence of $p$-toluenesulfonic acid with removal of water afforded a mixture consisting of the $\alpha$-acetoxy-ester (6) and $\alpha$-hydroxy-ester (7), the former of which was easily converted to the latter by hydrolysis with lithium carbonate in methanol. After protection of the hydroxyl group with a tert-butyldiphenylsilyl (TBDPS) group, hydrogenation of the resulting ester $(\mathbf{8})$ on palladium carbon furnished the acid (9) in good yield. Esterification of the acid (9) with the oxide-ester $(\mathbf{1 0})^{6)}$ with dicyclohexyl- carbodiimide (DCC) in the presence of 4-pyrrolidinopyridine $^{9)}$ gave the ester (11) in $86 \%$ yield without racemization at the $\alpha$-carbon of the acid (9). De-silylation of the ester (11) with tetrabutylammonium fluoride (TBAF) gave the hydroxy-ester (12) which has the entire carbon framework corresponding to AF-toxin IIc methyl ester. Although the proton nuclear magnetic resonance $\left({ }^{1} \mathrm{H}-\mathrm{NMR}, 400 \mathrm{MHz}\right)$ spectrum of the synthetic compound (12) exhibited a close similarity to that of AF-toxin IIc methyl ester reported in the literature ${ }^{1)}$ the chemical shifts of the primary $(0.88,3 \mathrm{H}$, t) and secondary methyl $(0.99,3 \mathrm{H}, \mathrm{d})$ groups in the synthesized ester (12) showed remarkable differences from the methyl ester obtained from natural sources $(0.97,3 \mathrm{H}$, $\mathrm{t}$ and $0.87,3 \mathrm{H}, \mathrm{d})$. Thus, we aimed at the synthesis of the diastereoisomeric $\alpha$-hydroxy-acid (13). Treatment of the $\alpha$-hydroxy-ester (7) with ethyl diazodicarboxylate and triphenylphosphine in formic acid ${ }^{10)}$ gave the formyl ester (14). Mild hydrolysis of $\mathbf{1 4}$ with lithium carbonate in methanol gave the hydroxy-ester (15). Its ${ }^{1} \mathrm{H}-\mathrm{NMR}$ spectrum and $[\alpha]_{D}$ value are different from those of the hydroxy-ester (7) mentioned above. The same reaction sequence on the hydroxy-ester (15) as for the ester (7) gave the acid (16) in $68 \%$ overall yield. The same reaction sequence (condensation of $\mathbf{1 0}$ and $\mathbf{1 6}$ followed by the de-silylation reaction) furnished AF-toxin IIc methyl ester (2b) in $75 \%$ yield. Accomplishment of the synthesis was confirmed by the identity of the ${ }^{1} \mathrm{H}-\mathrm{NMR}$ spectral data of the synthetic compound with reported values. ${ }^{1)}$

Next, we turned our attention to the synthesis of AFtoxin IIa methyl ester (3b), which has a 6,7-cis double bond in the trienoic acid moiety and shows strong toxicity to Japanese white pear. An attempt to form the cis olefin by Wittig reaction of the aldehyde $(17)^{6)}$ with methyl 4triphenylphosphonium crotonate and lithium methoxide ${ }^{6)}$ was unsuccessful, resulting in formation of the trans-trans ester (18), identical with an authentic sample, ${ }^{6}$ ) in low yield. Then, we planned to form the cis double bond by a partial
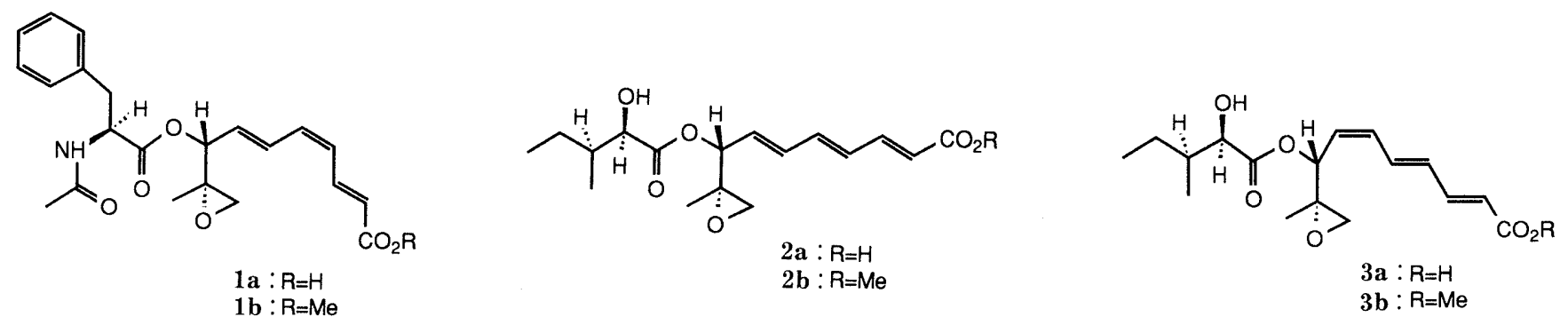

Chart 1 
$\overbrace{T_{H}^{H}}^{R_{i}^{1}} C O_{2} R^{2}$

$4: \mathrm{R}^{1}=\mathrm{NH}_{2} ; \mathrm{R}^{2}=\mathrm{H}$

$5: R^{1}=O A C ; R^{2}=H$

$6: \mathrm{R}^{1}=\mathrm{OAc} ; \mathrm{R}^{2}=\mathrm{CH}_{2} \mathrm{Ph}$

$7: R^{1}=\mathrm{OH} ; \quad R^{2}=\mathrm{CH}_{2} \mathrm{Ph}$

$8: \mathrm{R}^{1}=$ OTBDPS; $\mathrm{R}^{2}=\mathrm{CH}_{2} \mathrm{Ph}$

$9: R^{1}=$ OTBDPS; $R^{2}=H$

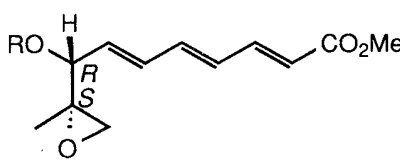

$10: R=H$

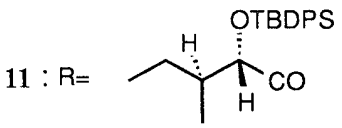
$\mathrm{H} \stackrel{\mathrm{OH}}{\vdots}$

$12: R=$

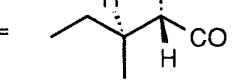

$13: \mathrm{R}^{1}=$ OTBDPS; $\mathrm{R}^{2}=\mathrm{CH}_{2} \mathrm{Ph}$

$14: R^{1}=\mathrm{OCHO} ; R^{2}=\mathrm{CH}_{2} \mathrm{Ph}$

$15: \mathrm{R}^{1}=\mathrm{OH} ; \mathrm{R}^{2}=\mathrm{CH}_{2} \mathrm{Ph}$

$16: R^{1}=$ OTBDPS; $R^{2}=H$

Chart 2<smiles></smiles>

17<smiles>C=C(C)C(C=CC=CC(C)=O)OCCCC</smiles>

19

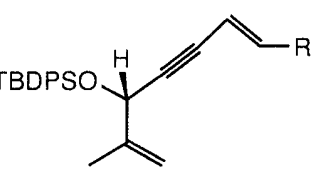

$22: \mathrm{R}=\mathrm{CO}_{2} \mathrm{Me}$

$23: \mathrm{R}=\mathrm{CH}_{2} \mathrm{OH}$

$24: \mathrm{R}=\mathrm{CHO}$<smiles>C=C(C)C(C=C(Br)Br)(OC(C)C)OC(C)(C)C</smiles>

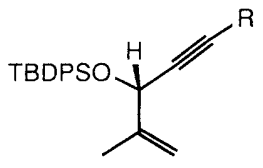

$20: \mathrm{R}=\mathrm{H}$ $21: \mathrm{R}=\mathrm{CHO}$

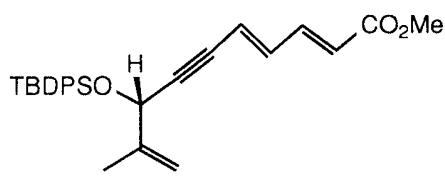

25
Chart 3 reduction of a triple bond.

Treatment of the aldehyde $(\mathbf{1 7})^{6)}$ with carbon tetrabromide and triphenylphosphine ${ }^{11)}$ gave the dibromide (19) in $73 \%$ yield. The bromide was smoothly transformed to the acetylene (20) by treatment with $n$-butyllithium followed by water in $65 \%$ yield. Lithiation of the acetylene (20) with $n$-butyllithium and treatment of the resulting lithio compound with dimethylformamide (DMF) in tetrahydrofuran (THF) at $-78{ }^{\circ} \mathrm{C}$ gave the aldehyde (21) in $86 \%$ yield. Direct treatment of the reaction mixture of the acetylene formation reaction with DMF did not give a good result. The aldehyde (21) was subjected to a WadsworthEmmons reaction with trimethyl phosphonoacetate, affording the ester (22) in $87 \%$ yield. The structure of this product was confirmed by its ${ }^{1} \mathrm{H}-\mathrm{NMR}$ spectrum, which showed signals at $\delta 5.97(1 \mathrm{H}, J=16 \mathrm{~Hz})$ and $6.63(1 \mathrm{H}, \mathrm{dd}, J=16$ and $1.8 \mathrm{~Hz}$ ) assigned to two olefinic protons on a newly formed trans-double bond. Reduction of 22 with diisobutylaluminum hydride (DIBAL-H) followed by oxidation $\left(\mathrm{MnO}_{2}\right)$ gave the aldehyde (24) in good yield. Wadsworth-Emmons reaction on the aldehyde (24) gave the ester (25) having a trans diene. Epoxidation of $\mathbf{2 5}$ with $m$-chloroperbenzoic acid ( $m$ CPBA) gave a mixture (revealed by its ${ }^{1} \mathrm{H}$-NMR spectrum $(400 \mathrm{MHz})$ ) of the oxides (26a and 26b), but both oxides showed the same $R f$ values on thin layer chromatography with several solvent systems. An attempt to isolate each oxide in pure form was unsuccessful.

Hydrogenation of $\mathbf{2 2}$ with Lindlar catalyst gave the cis-trans diene-ester (27) in $87 \%$ yield. Its ${ }^{1} \mathrm{H}-\mathrm{NMR}$ spectrum exhibited two doublet signals at $\delta 5.91(\mathrm{t}$, $J=11.7 \mathrm{~Hz})$ and $5.71(\mathrm{dd}, J=11.7$ and $8.4 \mathrm{~Hz})$, confirming the cis geometry of the newly formed double bond. The same reaction sequence on 27 (DIBAL-H reduction, manganese dioxide oxidation, and Wadsworth-Emmons reaction) gave the cis-trans-trans-trienoic acid ester (29). The structure of 29 was also confirmed by its ${ }^{1} \mathrm{H}-\mathrm{NMR}$ spectrum $(7.04$ and $\delta 5.80$ ( $1 \mathrm{H}$ each, $J=15.4 \mathrm{~Hz})$ ). Oxidation of 29 with $m$ CPBA gave a mixture of two diastereoisomers $(\mathbf{3 0 a})$ and $(\mathbf{3 0 b})$ in a $1: 1$ ratio. In this case, both isomers were isolated in pure forms by preparative thin layer chromatography and flash chromatography. Stereostructures of both oxides were proposed on the basis of their ${ }^{1} \mathrm{H}-\mathrm{NMR}$ spectra. Thus, one of the isomers showed signals at $\delta 2.53$ and $2.64(1 \mathrm{H}$ each, $J=4.6 \mathrm{~Hz})$ and the other showed signals at $\delta 2.55$ and $2.63(1 \mathrm{H}$ each, $J=4.9 \mathrm{~Hz}$ ), respectively, as a pair of $\mathrm{AB}$-quartets assigned to the methylene protons of the oxide moiety. It is possible to

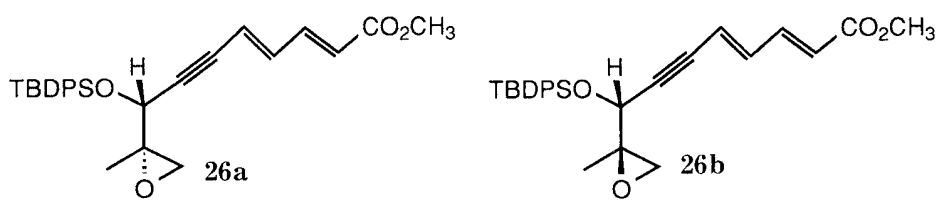

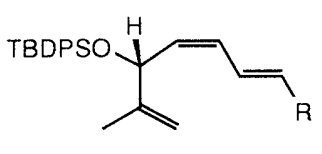

$27: \mathrm{R}=\mathrm{CO}_{2} \mathrm{Me}$ $\begin{array}{l:l}27 & \mathrm{R}=\mathrm{CO}_{2} \mathrm{M} \\ 28 & \mathrm{R}=\mathrm{CHO}\end{array}$



29<smiles>CCC(C)C([OH2+])C(=O)OC(/C=C\C=C\C=C\C(C)C)(C(=O)OC)C1(C)CO1</smiles>

Chart 4

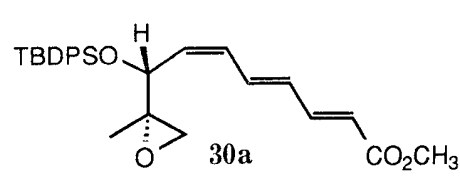<smiles>C/C=C/C=C/C=C\C(OS(C)(=O)=O)C1(C)CO1</smiles>

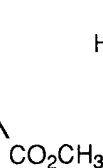

3

$$
\text { (1) }
$$$$
\text { 政 }
$$ 
discriminate the structures of these compounds based on the fact $^{6)}$ that an oxide exhibiting larger chemical shift difference of the AB-signal has $(R)$ and $(S)$ configuration at the carbons bearing the silyloxy and the oxide oxygen, respectively. Thus, the former (30a) has $(R)$ and $(S)$ configurations and the other (30b) has $(R)$ and $(R)$ configurations at these carbons. The discrimination was ultimately confirmed by successful synthesis of AF-toxin IIa methyl ester. Treatment of $\mathbf{3 0 a}$ with TBAF gave the $(8 R)$ - $(9 S)$-hydroxy-cis-trans--trans ester (31a) in $45 \%$ yield. The acylation of $\mathbf{3 1}$ with the $\alpha$-silyloxy-acid (16) in the same manner as mentioned above gave the ester (32) in $40 \%$ yield. Deprotection of the TBDPS group of $\mathbf{3 2}$ with TBAF in methylene chloride afforded AF-toxin IIa methyl ester (3b). Success in the synthesis of AF-toxin II methyl ester was confirmed by comparison of the ${ }^{1} \mathrm{H}-\mathrm{NMR}$ spectral data with those ${ }^{1)}$ of AF-toxin II methyl ester obtained from natural sources. The synthetic AF-toxin IIa and IIc are toxic to Japanese white pear, as evaluated on leaves of the plant.

\section{Experimental}

Melting points were determined on a Yanagimoto micro-melting point apparatus and are uncorrected. Infrared (IR) spectra were recorded on a Shimadzu IR-408 spectrometer in chloroform. ${ }^{1} \mathrm{H}-\mathrm{NMR}$ spectra were recorded on JEOL PMX-60, JEOL FX 90Q, and JNM-GX 400 NMR spectrometers with tetramethylsilane as an internal standard and chemical shifts are given in $\delta(\mathrm{ppm})$. Optical rotations were measured with a JASCO DIP-181 digital polarimeter and high-resolution mass (HR-MS) spectra were taken with a JEOL JMS-DX303 instrument. Column chromatography was performed with Kieselgel 60G (70-230 mesh) and flash column chromatography was performed with Kieselgel 60G (Art 7731). Homogeneities of the compounds cited in this report were confirmed by examination of the ${ }^{1} \mathrm{H}-\mathrm{NMR}$ spectra and by thin layer chromatography.

2(S)-Acetoxy-3(S)-methylpentanoic Acid (5) $\mathrm{NaNO}_{2}(4.8 \mathrm{~g}, 69.6 \mathrm{mmol})$ was added in portions to a stirred solution of L-isoleucine (4) (7.84 g, $59.8 \mathrm{mmol})$ in $\mathrm{AcOH}(72 \mathrm{ml})$ over $4.5 \mathrm{~h}$ at $30-35^{\circ} \mathrm{C}$, and the whole was allowed to stand overnight at room temperature. The solvent was evaporated off in vacuo to give a residue, which was shaken vigorously with a mixture of ether $(120 \mathrm{ml})$, water $(10 \mathrm{ml})$ and concentrated $\mathrm{HCl}$ $(6 \mathrm{ml})$. After washing of the ethereal layer with water, the ethereal layer was extracted with $10 \%$ aqueous $\mathrm{Na}_{2} \mathrm{CO}_{3}$. The aqueous extracts were combined, and acidified with concentrated $\mathrm{HCl}$, and extracted with ether. The ethereal layer was washed with brine, dried over anhydrous $\mathrm{Na}_{2} \mathrm{SO}_{4}$, and concentrated to dryness to give the acid $(5)(8.9 \mathrm{~g}, 85 \%)$ as a yellow oil. IR $\left(\mathrm{CHCl}_{3}\right): 1720,1740 \mathrm{~cm}^{-1}$. ${ }^{1} \mathrm{H}-\mathrm{NMR}\left(90 \mathrm{MHz}\right.$ in $\left.\mathrm{CDCl}_{3}\right): 0.85$ $(3 \mathrm{H}, \mathrm{t}, J=7.2 \mathrm{~Hz}), 1.01(3 \mathrm{H}, \mathrm{d}, J=7.2 \mathrm{~Hz}), 1.30-1.62(3 \mathrm{H}, \mathrm{m}), 2.15(3 \mathrm{H}$, s), $4.95(\mathrm{IH}, \mathrm{d} J=4.8 \mathrm{~Hz}), 10.3(1 \mathrm{H}, \mathrm{s}),[\alpha]_{\mathrm{D}}^{25}=+14.6^{\circ}(c=1.00$, EtOH $)$. MS $m / z: 174\left(\mathrm{M}^{+}\right)$.

Benzyl 2(S)-Acetoxy-3(S)-methylpentanoate (6) and Benzyl 2(S)-Hydroxy-3(S)-methylpentanoate (7) A mixture of the acid (5) $(5.0 \mathrm{~g}, 28.7$ $\mathrm{mmol}), p$-toluenesulfonic acid $(0.5 \mathrm{~g})$ and benzyl alcohol $(10.0 \mathrm{~g}, 92.6 \mathrm{mmol})$ in dry benzene $(60 \mathrm{ml})$ was refluxed overnight with azeotropic removal of water under argon. The solvent was evaporated off in vacuo and the residue was dissolved in ether $(100 \mathrm{ml})$. The ethereal solution was washed with $3 \%$ aqueous $\mathrm{Na}_{2} \mathrm{CO}_{3}$, and water, dried with $\mathrm{MgSO}_{4}$ and concentrated to dryness to give a residue, which was chromatographed on silica gel in hexane-chloroform $(1: 1)$. Elution with the same solvent gave the benzyl acetoxypentanoate (6) $(2.25 \mathrm{~g}, 32 \%)$ and the hydroxypentanoate (7) $(2.40 \mathrm{~g}$, $35.3 \%$ ) in that order as colorless oils.

Benzyl 2(S)-Acetoxy-3(S)-methylpentanoate (6): IR $\left(\mathrm{CHCl}_{3}\right): 1740$ $\mathrm{cm}^{-1} .{ }^{1} \mathrm{H}-\mathrm{NMR}\left(90 \mathrm{MHz}\right.$ in $\left.\mathrm{CDCl}_{3}\right): 0.88(3 \mathrm{H}, \mathrm{t}, J=7.2 \mathrm{~Hz}), 0.96(3 \mathrm{H}$, $\mathrm{d}, J=7.2 \mathrm{~Hz}), 1.15-1.90(3 \mathrm{H}, \mathrm{m}), 2.10(3 \mathrm{H}, \mathrm{s}), 4.93(\mathrm{IH}, \mathrm{d}, J=4.8 \mathrm{~Hz})$, $5.17(2 \mathrm{H}, \mathrm{s}), 7.33(5 \mathrm{H}, \mathrm{brs}) .[\alpha]_{\mathrm{D}}^{27}=-27.6^{\circ}(c=1.25$, EtOH $)$. HR-MS $m / z$ : Calcd for $\mathrm{C}_{15} \mathrm{H}_{20} \mathrm{O}_{4}\left(\mathrm{M}^{+}\right): 264.1362$. Found: 264.1341 .

Benzyl 2(S)-Hydroxy-3(S)-methylpentanoate (7): IR $\left(\mathrm{CHCl}_{3}\right): 1725$, $3540 \mathrm{~cm}^{-1}$. ${ }^{1} \mathrm{H}-\mathrm{NMR}\left(90 \mathrm{MHz}\right.$ in $\left.\mathrm{CDCl}_{3}\right): 0.86(3 \mathrm{H}, \mathrm{t}, J=7.2 \mathrm{~Hz}), 0.98$ $(3 \mathrm{H}, \mathrm{d}, J=7.2 \mathrm{~Hz}), 1.15-1.90(3 \mathrm{H}, \mathrm{m}), 2.72(1 \mathrm{H}, \mathrm{d}, J=6.2 \mathrm{~Hz}), 4.12(1 \mathrm{H}$, $\mathrm{dd}, J=6.2,4.8 \mathrm{~Hz}), 5.20(2 \mathrm{H}, \mathrm{s}), 7.35(5 \mathrm{H}, \mathrm{s}) .[\alpha]_{\mathrm{D}}^{27}=-11.8^{\circ}(c=1.00$, EtOH). HR-MS $m / z$ : Calcd for $\mathrm{C}_{13} \mathrm{H}_{18} \mathrm{O}_{3}\left(\mathrm{M}^{+}\right)$: 222.1256. Found:

\subsection{2}

Hydrolysis of the Acetate (6) A mixture of the acetoxycarboxylate 6 $(270 \mathrm{mg}, 1.0 \mathrm{mmol})$ and lithium carbonate $(45 \mathrm{mg}, 1.2 \mathrm{mmol})$ in methanol $(10 \mathrm{ml})$ was stirred at room temperature for $15 \mathrm{~h}$. The reaction mixture was concentrated in vacuo to afford a residue, which was extracted with ether. The ethereal solution was washed with $3 \%$ aqueous $\mathrm{HCl}, 3 \%$ aqueous $\mathrm{Na}_{2} \mathrm{CO}_{3}$ and water, and dried with $\mathrm{MgSO}_{4}$. Removal of the solvent gave $7(172 \mathrm{mg}, 76 \%)$.

Benzyl 2(S)-(tert-Butyldiphenylsiloxy)-3(S)-methyl Pentanoate (8) A mixture of $7(2.9 \mathrm{~g}, 13 \mathrm{mmol})$, tert-butylchlorodiphenylsilane $(4.7 \mathrm{~g}$, $17 \mathrm{mmol})$ and imidazole $(1.2 \mathrm{~g}, 17 \mathrm{mmol})$ in dry DMF $(20 \mathrm{ml})$ was stirred at room temperature for $12 \mathrm{~h}$, diluted with $3 \%$ aqueous $\mathrm{NH}_{4} \mathrm{Cl}$, and extracted with ether. The ethereal extract was washed with $3 \%$ aqueous $\mathrm{NH}_{4} \mathrm{Cl}, 3 \%$ aqueous $\mathrm{Na}_{2} \mathrm{CO}_{3}$ and water, dried with $\mathrm{MgSO}_{4}$ and concentrated. The residue was chromatographed on silica gel in hexaneacetone $(100: 2)$ to give the TBDPS-ester $(8)(4.5 \mathrm{~g}, 75 \%)$ as a colorless oil. IR $\left(\mathrm{CHCl}_{3}\right): 1740 \mathrm{~cm}^{-1} \cdot{ }^{1} \mathrm{H}-\mathrm{NMR}\left(90 \mathrm{MHz}\right.$ in $\left.\mathrm{CDCl}_{3}\right): 0.82$ $(3 \mathrm{H}, \mathrm{t}, J=6.8 \mathrm{~Hz}), 0.85(3 \mathrm{H}, \mathrm{d}, J=6.8 \mathrm{~Hz}), 1.08(9 \mathrm{H}, \mathrm{s}), 1.03-1.92(3 \mathrm{H}$ $\mathrm{m}), 4.16(1 \mathrm{H}, \mathrm{d}, J=4.6 \mathrm{~Hz}), 4.77(2 \mathrm{H}, \mathrm{s}), 7.20-7.81 \quad(15 \mathrm{H}, \mathrm{m})$. $[\alpha]_{\mathrm{D}}^{26}=-44.8^{\circ}(c=1.35, \mathrm{EtOH})$. MS $m / z: 460\left(\mathrm{M}^{+}\right)$.

2(S)-(tert-Butyldiphenylsiloxy)-3(S)-methylpentanoic Acid (9) A suspension of the TBDPS-ester $(8)(1.0 \mathrm{~g}, 2.2 \mathrm{mmol})$ and $10 \%$ palladium carbon $(2.0 \mathrm{~g})$ in ethanol $(50 \mathrm{ml})$ was stirred under $\mathrm{H}_{2}$ for $2 \mathrm{~h}$. The reaction mixture was filtered and the filtrate was concentrated in vacuo to afford the acid (9) $(470 \mathrm{mg}, 75 \%)$ as a colorless oil. IR $\left(\mathrm{CHCl}_{3}\right): 3520-2510$, $1770,1720 \mathrm{~cm}^{-1} \cdot{ }^{1} \mathrm{H}-\mathrm{NMR}\left(60 \mathrm{MHz}\right.$ in $\left.\mathrm{CDCl}_{3}\right): 0.78(3 \mathrm{H}, \mathrm{t}, J=6.8 \mathrm{~Hz})$, $0.85(3 \mathrm{H}, \mathrm{d}, J=6.8 \mathrm{~Hz}), 1.11(9 \mathrm{H}, \mathrm{s}), 1.01-1.85(3 \mathrm{H}, \mathrm{m}), 4.19(1 \mathrm{H}, \mathrm{d}$, $J=4.6 \mathrm{~Hz}), 7.2 \mathrm{l}-7.85(10 \mathrm{H}, \mathrm{m})$. HR-MS $m / z$ : Calcd for $\mathrm{C}_{22} \mathrm{H}_{30} \mathrm{O}_{3} \mathrm{Si}$ $\left(\mathrm{M}^{+}\right): 370.1965$. Found: 370.1977 .

Methyl $9(S), 10$-Epoxy-8(R)-(2'(S)-tert-butyldiphenylsiloxy-3'(S)methylpentanoyloxy)-9-methyl-deca- $(E, E, E)$-trienoate (11) A solution of DCC (332 mg, $1.5 \mathrm{mmol})$ and the acid (9) $(596 \mathrm{mg}, 1.5 \mathrm{mmol})$ in methylene chloride $(4 \mathrm{ml})$ was stirred at room temperature under argon for $1.5 \mathrm{~h}$, then the oxide-ester $(10)^{5 b)}(110 \mathrm{mg}, 0.49 \mathrm{mmol})$ and 4-pyrrolidinopyridine $(40 \mathrm{mg})$ were added and the resulting mixture was stirred at the same temperature for $12 \mathrm{~h}$, diluted with ether $(30 \mathrm{ml})$ and filtered. The filtrate was washed with $3 \%$ aqueous $\mathrm{Na}_{2} \mathrm{CO}_{3}, 3 \%$ aqueous $\mathrm{NH}_{4} \mathrm{Cl}$ and brine, dried with $\mathrm{MgSO}_{4}$ and concentrated. The residue was chromatographed on silica gel in hexane ethyl acetate $(100: 4)$ to give the ester (11) $(269 \mathrm{mg}$ $95 \%)$ as a pale yellow oil. IR $\left(\mathrm{CHCl}_{3}\right): 1750,1720 \mathrm{~cm}^{-1} \cdot{ }^{1} \mathrm{H}-\mathrm{NMR}(90 \mathrm{MHz}$ in $\left.\mathrm{CDCl}_{3}\right): 0.79(3 \mathrm{H}, \mathrm{t}, J=7.2 \mathrm{~Hz}), 0.93(3 \mathrm{H}, \mathrm{d}, J=7.2 \mathrm{~Hz}), 1.09(9 \mathrm{H}, \mathrm{s})$, $1.14(3 \mathrm{H}, \mathrm{s}), 1.14-1.96(3 \mathrm{H}, \mathrm{m}), 2.47(\mathrm{lH}, \mathrm{d}, J=4.8 \mathrm{~Hz}), 2.61(1 \mathrm{H}, \mathrm{d}$, $J=4.8 \mathrm{~Hz}), 3.74(3 \mathrm{H}, \mathrm{s}), 4.23(1 \mathrm{H}, \mathrm{d}, J=4.2 \mathrm{~Hz}), 4.99(1 \mathrm{H}, \mathrm{d}, J=7.3 \mathrm{~Hz})$, $5.58(1 \mathrm{H}, \mathrm{dd}, J=14.3,7.3 \mathrm{~Hz}), 5.8 \mathrm{I}(1 \mathrm{H}, \mathrm{d}, J=15.4 \mathrm{~Hz}), 6.05-6.49(3 \mathrm{H}$, m), 7.14-7.72 $(11 \mathrm{H}, \mathrm{m}) .[\alpha]_{\mathrm{D}}^{17}=-67.7^{\circ}(c=0.98$, EtOH). HR-MS $m / z$ : Calcd for $\mathrm{C}_{34} \mathrm{H}_{44} \mathrm{O}_{6} \mathrm{Si}\left(\mathrm{M}^{+}\right)$: 576.2908. Found: 576.2912 .

The Diastereoisomer (12) of AF-Toxin IIc Methyl Ester (2a) TBAF $(0.21 \mathrm{ml}, 0.2 \mathrm{mmol}, 1 \mathrm{M}$ in THF) was added dropwise to a solution of the ester (11) $(60 \mathrm{mg}, 0.1 \mathrm{mmol})$ in dry THF $(2 \mathrm{ml})$ at $-10^{\circ} \mathrm{C}$ under argon and the resulting mixture was stirred at the same temperature for $10 \mathrm{~min}$ and at room temperature for $1 \mathrm{~h}$, and then diluted with ether $(30 \mathrm{ml})$. The ethereal solution was washed with brine, dried with $\mathrm{MgSO}_{4}$ and concentrated. The residue was chromatographed on silica gel in chloroform to afford the hydroxy-ester (12) $(24 \mathrm{mg}, 68 \%)$ as a pale yellow oil. IR $\left(\mathrm{CHCl}_{3}\right): 3540,1750,1720 \mathrm{~cm}^{-1}$. ${ }^{1} \mathrm{H}-\mathrm{NMR}\left(400 \mathrm{MHz}\right.$ in $\left.\mathrm{CDCl}_{3}\right)$ : $0.89(3 \mathrm{H}, \mathrm{t}, J=7.2 \mathrm{~Hz}), 0.99(3 \mathrm{H}, \mathrm{d}, J=7.2 \mathrm{~Hz}), 1.17-1.36(2 \mathrm{H}, \mathrm{m})$, $1.37(3 \mathrm{H}, \mathrm{s}), 1.87(1 \mathrm{H}, \mathrm{m}), 2.64(1 \mathrm{H}, \mathrm{d}, J=4.8 \mathrm{~Hz}), 2.79(1 \mathrm{H}, \mathrm{d}, J=$ $4.8 \mathrm{~Hz}), 3.76(3 \mathrm{H}, \mathrm{s}), 4.13(1 \mathrm{H}, \mathrm{d}, J=4.3 \mathrm{~Hz}), 5.32(1 \mathrm{H}, \mathrm{d}, J=7.5 \mathrm{~Hz})$, $5.80(1 \mathrm{H}, \mathrm{dd}, J=14.5,7.5 \mathrm{~Hz}), 5.93(1 \mathrm{H}, \mathrm{d}, J=15.8 \mathrm{~Hz}), 6.36(1 \mathrm{H}, \mathrm{dd}$, $J=15.1,11.5 \mathrm{~Hz}), 6.43(1 \mathrm{H}, \mathrm{dd}, J=14.5,10.8 \mathrm{~Hz}), 6.52(1 \mathrm{H}, \mathrm{dd}, J=15.1$, $10.8 \mathrm{~Hz}), 7.29(1 \mathrm{H}, \mathrm{dd}, J=15.8,11.5 \mathrm{~Hz}),[\alpha]_{\mathrm{D}}^{16}=+3.0^{\circ} \quad(c=0.67$, EtOH). HR-MS $m / z$ : Calcd for $\mathrm{C}_{18} \mathrm{H}_{26} \mathrm{O}_{6}\left(\mathrm{M}^{+}\right)$: 338.1730. Found: 338.1787.

Benzyl 2(R)-Formyloxy-3(S)-methylpentanoate (14) Diethylazodicarboxylate $(226 \mathrm{mg}, 1.3 \mathrm{mmol})$ in dry ether $(2 \mathrm{ml})$ was added dropwise to a solution of the $(S)$-benzyl ester (7) $(144 \mathrm{mg}, 0.65 \mathrm{mmol})$, triphenylphosphine $(340 \mathrm{mg}, 1.3 \mathrm{mmol})$ and formic acid $(60 \mathrm{mg}, 1.3 \mathrm{mmol})$ in dry ether $(4 \mathrm{ml})$ and the resulting mixture was stirred at room temperature for $24 \mathrm{~h}$, diluted with ether $(35 \mathrm{ml})$, and filtered. The filtrate was washed with $3 \%$ aqueous $\mathrm{NaHCO}_{3}, 3 \%$ aqueous $\mathrm{NH}_{4} \mathrm{Cl}$ and water, dried with $\mathrm{MgSO}_{4}$ and concentrated. The residue was chromatographed on silica gel in hexane-ethyl acetate $(100: 4)$ to give the formyl-ester (14) $(166 \mathrm{mg}, 72 \%)$ as a colorless oil. IR $\left(\mathrm{CHCl}_{3}\right): 1720 \mathrm{~cm}^{-1} \cdot{ }^{1} \mathrm{H}-\mathrm{NMR}\left(90 \mathrm{MHz}\right.$ in $\left.\mathrm{CDCl}_{3}\right)$ : $0.90(3 \mathrm{H}, \mathrm{t}, J=7.2 \mathrm{~Hz}), 0.92(3 \mathrm{H}, \mathrm{d}, J=7.2 \mathrm{~Hz}), 1.18-1.51(2 \mathrm{H}, \mathrm{m})$, $1.69-2.13(1 \mathrm{H}, \mathrm{m}), 5.19(2 \mathrm{H}, \mathrm{s}), 5.24(1 \mathrm{H}, \mathrm{d}, J=4.3 \mathrm{~Hz}), 7.34(5 \mathrm{H}, \mathrm{s})$, 
$8.16(1 \mathrm{H}, \mathrm{s}) .[\alpha]_{\mathrm{D}}^{22}=+23.3^{\circ}(c=1.20, \mathrm{EtOH}) . \mathrm{MS} m / z: 256\left(\mathrm{M}^{+}\right)$

Benzyl 2(R)-Hydroxy-3(S)-methylpentanoate (15) A mixture of the formyl ester (14) $(650 \mathrm{mg}, 2.6 \mathrm{mmol})$ and lithium carbonate $(260 \mathrm{mg}$, $3.1 \mathrm{mmol})$ in methanol-water $(14: 1)$ was stirred at room temperature for $2 \mathrm{~h}$ and concentrated in vacuo to give a residue, which was extracted with ether. The ethereal solution was washed with $3 \%$ aqueous $\mathrm{Na}_{2} \mathrm{CO}_{3}, 3 \%$ aqueous $\mathrm{NH}_{4} \mathrm{Cl}$ and water, and dried with $\mathrm{MgSO}_{4}$. Removal of the solvent afforded the hydroxy-ester (15) $(554 \mathrm{mg}, 96 \%)$ as a colorless oil. IR $\left(\mathrm{CHCl}_{3}\right): 3500,1715 \mathrm{~cm}^{-1}$. ${ }^{1} \mathrm{H}-\mathrm{NMR}\left(90 \mathrm{MHz}\right.$ in $\left.\mathrm{CDCl}_{3}\right): 0.78(3 \mathrm{H}, \mathrm{d}$, $J=7.2 \mathrm{~Hz}), 0.92(3 \mathrm{H}, \mathrm{t}, J=7.2 \mathrm{~Hz}), 1.00-1.98(3 \mathrm{H}, \mathrm{m}), 2.67(1 \mathrm{H}, \mathrm{d}$, $J=5.8 \mathrm{~Hz}), 4.22(1 \mathrm{H}, \mathrm{dd}, J=3.2,5.8 \mathrm{~Hz}), 5.21(2 \mathrm{H}, \mathrm{s}), 7.32(5 \mathrm{H}, \mathrm{s})$. $[\alpha]_{\mathrm{D}}^{23}=+9.0^{\circ}(c=1.05, \mathrm{EtOH})$. HR-MS $m / z$ : Calcd for $\mathrm{C}_{13} \mathrm{H}_{18} \mathrm{O}_{3}\left(\mathrm{M}^{+}\right)$: 222.1256. Found: 222.1244.

2(R)-(tert-Butyldiphenylsiloxy)-2(S)-methylpentanoic Acid (16) By use of the same procedure as described for the preparation of the acid (9) from 7 , the hydroxy-ester (15) $(256 \mathrm{mg}, 1.15 \mathrm{mmol})$ gave the acid (16) (374 $\mathrm{mg}, 87 \%$ overall yield) as a colorless oil. IR $\left(\mathrm{CHCl}_{3}\right): 3520-2510$, $1760,1720 \mathrm{~cm}^{-1} .{ }^{1} \mathrm{H}-\mathrm{NMR}\left(90 \mathrm{MHz}\right.$ in $\left.\mathrm{CDCl}_{3}\right): 0.76(3 \mathrm{H}, \mathrm{t}, J=7.2 \mathrm{~Hz})$, $0.91(3 \mathrm{H}, \mathrm{d}, J=7.2 \mathrm{~Hz}), 1.11(9 \mathrm{H}, \mathrm{s}), 1.10-1.83(3 \mathrm{H}, \mathrm{m}), 4.19(1 \mathrm{H}, \mathrm{d}$, $J=4.1 \mathrm{~Hz}), 7.24-7.73(10 \mathrm{H}, \mathrm{m}) .[\alpha]_{\mathrm{D}}^{22}=+18.5^{\circ}(c=1.01, \mathrm{EtOH})$. HR-MS $m / z$ : Calcd for $\mathrm{C}_{22} \mathrm{H}_{30} \mathrm{O}_{3} \mathrm{Si}\left(\mathrm{M}^{+}\right): 370.1965$. Found 370.1952 .

AF-Toxin IIc Methyl Ester (2a) By use of the procedure as described for the preparation of 12, coupling of the epoxy-ester (10) (123 mg, $0.33 \mathrm{mmol})$ and $16(150 \mathrm{mg}, 0.40 \mathrm{mmol})$ gave AF-toxin IIc methyl ester (2a) $\left(72 \mathrm{mg}, 65 \%\right.$ overall yield) as a colorless oil. IR $\left(\mathrm{CHCl}_{3}\right): 1620,1720$, $1720 \mathrm{~cm}^{-1}$. ${ }^{1} \mathrm{H}-\mathrm{NMR}\left(400 \mathrm{MHz}\right.$ in $\left.\mathrm{CDCl}_{3}\right): 0.86(3 \mathrm{H}, \mathrm{d}, J=6.9 \mathrm{~Hz}), 0.98$ $(3 \mathrm{H}, \mathrm{t}, J=7.4 \mathrm{~Hz}), 1.36(3 \mathrm{H}, \mathrm{s}), 1.36-1.40(2 \mathrm{H}, \mathrm{m}), 1.83(1 \mathrm{H}, \mathrm{m}), 2.61$ $(1 \mathrm{H}, \mathrm{d}, J=5.8 \mathrm{~Hz}), 2.63(1 \mathrm{H}, \mathrm{d}, J=4.8 \mathrm{~Hz}), 2.78(1 \mathrm{H}, \mathrm{d}, J=4.8 \mathrm{~Hz}), 3.75$ $(3 \mathrm{H}, \mathrm{s}), 4.23(1 \mathrm{H}, \mathrm{dd}, J=2.9,5.8 \mathrm{~Hz}), 5.35(1 \mathrm{H}, \mathrm{d}, J=7.3 \mathrm{~Hz}), 5.80(1 \mathrm{H}$, $\mathrm{dd}, J=7.3,14.8 \mathrm{~Hz}), 5.94(1 \mathrm{H}, \mathrm{d}, J=15.3 \mathrm{~Hz}), 6.38(1 \mathrm{H}, \mathrm{dd}, J=11.1$, $14.5 \mathrm{~Hz}), 6.43(1 \mathrm{H}, \mathrm{dd}, J=10.8,14.8 \mathrm{~Hz}), 6.53(1 \mathrm{H}, \mathrm{d}, J=14.5,10.8 \mathrm{~Hz})$, $7.29(1 \mathrm{H}, \mathrm{dd}, J=11.1,15.3 \mathrm{~Hz})$. HR-MS $m / z$ : Calcd for $\mathrm{C}_{18} \mathrm{H}_{26} \mathrm{O}_{6}\left(\mathrm{M}^{+}\right)$: 338.1730. Found: 338.1787

1,1-Dibromo-3(R)-tert-butyldiphenylsiloxy-4-methylpenta-1,4-diene (19) A solution of triphenylphosphine $(1.48 \mathrm{~g}, 4 \mathrm{mmol})$ in anhydrous methylene chloride $(3 \mathrm{ml})$ was added dropwise to a solution of carbon tetrabromide $(633 \mathrm{mg}, 2.0 \mathrm{mmol})$ in anhydrous methylene chloride $(6 \mathrm{ml})$ under argon at $0{ }^{\circ} \mathrm{C}$. The mixture was stirred at the same temperature for $5 \mathrm{~min}$, then zinc powder $(262 \mathrm{mg}, 4 \mathrm{mmol})$ and the aldehyde $(17)^{6)}(388 \mathrm{mg}, 1 \mathrm{mmol})$ were added alternately and the resulting mixture was stirred at room temperature for $3 \mathrm{~h}$ and diluted with ether $(50 \mathrm{ml})$. The ethereal solution was washed with water, dried with $\mathrm{MgSO}_{4}$ and concentrated to give a residue, which was chromatographed on silica gel in chloroform. Elution with the same solvent afforded the dibromide (19) $(360 \mathrm{mg}, 73 \%)$. IR $\left(\mathrm{CHCl}_{3}\right): 1625 \mathrm{~cm}^{-1} .{ }^{1} \mathrm{H}-\mathrm{NMR}\left(90 \mathrm{MHz}\right.$ in $\left.\mathrm{CDCl}_{3}\right): 1.09(9 \mathrm{H}, \mathrm{s}), 1.72$ $(3 \mathrm{H}, \mathrm{s}), 4.67(1 \mathrm{H}, \mathrm{d}, J=9.0 \mathrm{~Hz}), 4.95(1 \mathrm{H}, \mathrm{brs}), 5.18(1 \mathrm{H}, \mathrm{br} \mathrm{s}), 6.40(1 \mathrm{H}$, $\mathrm{d}, J=9.0 \mathrm{~Hz}), 7.26-7.71(10 \mathrm{H}, \mathrm{m}) .[\alpha]_{\mathrm{D}}^{21}=-80.6^{\circ}(c=1.01, \mathrm{EtOH}) . \mathrm{MS}$ $m / z: 494\left(\mathrm{M}^{+}\right)$.

3(R)-tert-Butyldiphenylsiloxy-4-methylpent-4-en-1-yne (20) nButyllithium $(1 \mathrm{ml}, 1.7 \mathrm{M}$ in hexane) was added to a solution of the dibromide (19) $(350 \mathrm{mg}, 0.7 \mathrm{mmol})$ in dry THF $(3 \mathrm{ml})$ at $-78^{\circ} \mathrm{C}$ under argon and the resulting mixture was stirred at the same temperature for $1 \mathrm{~h}$, and at $25^{\circ} \mathrm{C}$ for $1 \mathrm{~h}$. After addition of water $(2 \mathrm{ml})$, the reaction mixture was stirred at room temperature for $30 \mathrm{~min}$ and diluted with ether $(50 \mathrm{ml})$. The ethereal solution was washed with water, dried with $\mathrm{MgSO}_{4}$, and concentrated in vacuo to leave a residue, which was chromatographed on silica gel in chloroform. Elution with the same solvent gave the acetylene (20) $(154 \mathrm{mg}, 65 \%)$ as a colorless oil. IR $\left(\mathrm{CHCl}_{3}\right): 3290 \mathrm{~cm}^{-1},{ }^{1} \mathrm{H}-\mathrm{NMR}$ $\left(90 \mathrm{MHz}\right.$ in $\left.\mathrm{CDCl}_{3}\right): 1.09(9 \mathrm{H}, \mathrm{s}), 1.85(3 \mathrm{H}$, br s $), 2.35(1 \mathrm{H}, \mathrm{d}, J=2.2 \mathrm{~Hz})$, $4.37(1 \mathrm{H}, \mathrm{m}), 4.82(1 \mathrm{H}$, br s$), 4.94(1 \mathrm{H}$, brs $), 7.24-7.82(10 \mathrm{H}, \mathrm{m})$. $[\alpha]_{\mathrm{D}}^{24}=-47.3^{\circ}\left(c=1.00\right.$, EtOH). MS $m / z: 334\left(\mathrm{M}^{+}\right)$.

4(R)-tert-Butyldiphenylsiloxy-5-methyl-hex-5-en-1-ynal (21) nButyllithium $(1 \mathrm{ml}, 2.3 \mathrm{mmol})$ was added dropwise to a solution of the acetylene $(20)(480 \mathrm{mg}, 1.48 \mathrm{mmol})$ in dry THF $(5 \mathrm{ml})$ at $-78^{\circ} \mathrm{C}$ under argon, and the mixture was stirred at the same temperature for $2 \mathrm{~h}$. Then $\mathrm{DMF}(0.1 \mathrm{ml})$ was added and the resulting mixture was stirred at $-78^{\circ} \mathrm{C}$ for $4 \mathrm{~h}$ and diluted with ether $(30 \mathrm{ml})$. The ethereal solution was washed with water, dried with anhydrous $\mathrm{MgSO}_{4}$ and concentrated in vacuo to give a residue, which was chromatographed on silica gel in hexane-ether $(100: 5)$. Elution with the same solvent afforded the aldehyde (21) $(450 \mathrm{mg}$, $86 \%)$ as a colorless oil. IR $\left(\mathrm{CHCl}_{3}\right): 2200,1665 \mathrm{~cm}^{-1} \cdot{ }^{1} \mathrm{H}-\mathrm{NMR}(90 \mathrm{MHz}$ in $\left.\mathrm{CDCl}_{3}\right): 1.09(9 \mathrm{H}, \mathrm{s}), 1.84(3 \mathrm{H}, \mathrm{br} \mathrm{s}), 4.88(1 \mathrm{H}$, br s$), 4.91(1 \mathrm{H}$, br s), $5.04(1 \mathrm{H}$, br s $), 7.31-7.78(10 \mathrm{H}, \mathrm{m}), 9.30(1 \mathrm{H}, \mathrm{d}, J=0.7 \mathrm{~Hz}) . \mathrm{MS} m / z: 326$ $\left(\mathrm{M}^{+}\right)$.

Wadsworth-Emmons Reaction of the Aldehyde (21) A solution of tri- methylphosphonoacetate $(98 \mathrm{mg}, 0.54 \mathrm{mmol})$ in dry benzene $(2 \mathrm{ml})$ was added dropwise to a suspension of sodium hydride $(13 \mathrm{mg}, 0.45 \mathrm{mmol}$, $60 \%$ in oil) in benzene $(5 \mathrm{ml})$ at room temperature and the resulting mixture was stirred at room temperature under argon for $30 \mathrm{~min}$. Then a solution of the aldehyde $(21)(130 \mathrm{mg}, 0.36 \mathrm{mmol})$ in dry benzene $(2 \mathrm{ml})$ was added and the whole was stirred at room temperature for $30 \mathrm{~min}$, and diluted with ether $(30 \mathrm{ml})$. The ethereal solution was washed with $3 \%$ aqueous $\mathrm{NaHCO}_{3}, 3 \%$ aqueous $\mathrm{NH}_{4} \mathrm{Cl}$ and water, dried with $\mathrm{MgSO}_{4}$ and concentrated to give a residue, which was chromatographed on silica gel in hexane-ether $(100: 2)$. Elution with the same solvent afforded the diene-acetylene $(22)(130 \mathrm{mg}, 87 \%)$ as a colorless oil. IR $\left(\mathrm{CHCl}_{3}\right)$ : $1710 \mathrm{~cm}^{-1}$. ${ }^{1} \mathrm{H}-\mathrm{NMR}\left(90 \mathrm{MHz}\right.$ in $\left.\mathrm{CDCl}_{3}\right): 1.08(9 \mathrm{H}, \mathrm{s}), 1.84(3 \mathrm{H}$, br s), $3.73(3 \mathrm{H}, \mathrm{s}), 4.87(2 \mathrm{H}, \mathrm{brs}), 5.02(1 \mathrm{H}, \mathrm{m}), 5.97(1 \mathrm{H}, \mathrm{d}, J=15.8 \mathrm{~Hz}), 6.63$ $(\mathrm{lH}, \mathrm{dd}, J=15.8,1.8 \mathrm{~Hz}), 7.24-7.79(10 \mathrm{H}, \mathrm{m}) \cdot[\alpha]_{\mathrm{D}}^{24}=-95.0^{\circ}(c=1.30$ EtOH). HR-MS $m / z$ : Calcd for $\mathrm{C}_{26} \mathrm{H}_{30} \mathrm{O}_{3} \mathrm{Si}\left(\mathrm{M}^{+}\right)$: 418.1965. Found: 418.1942

6(R)-tert-Butyldiphenylsiloxy-7-methyl-octa-2,7-dien-4-yn-1-ol (23) DIBAL-H $(0.2 \mathrm{ml}, 0.36 \mathrm{mmol}, 25 \%$ (w/w) in $n$-hexane) was added to a solution of the ester (22) $(100 \mathrm{mg}, 0.24 \mathrm{mmol})$ in anhydrous methylene chloride $(2 \mathrm{ml})$ at $-78^{\circ} \mathrm{C}$ under argon. The resulting mixture was stirred at the same temperature for $1 \mathrm{~h}$. After addition of brine and chloroform $(50 \mathrm{ml})$ to the mixture, the whole was filtered. The chloroform solution was washed with brine, dried with $\mathrm{MgSO}_{4}$ and concentrated to give a residue, which was chromatographed on silica gel in benzene. The benzene eluate afforded the alcohol (23) $(84 \mathrm{mg}, 90 \%)$. IR $\left(\mathrm{CHCl}_{3}\right)$ : $3600,2255 \mathrm{~cm}^{-1}$. ${ }^{1} \mathrm{H}-\mathrm{NMR}\left(90 \mathrm{MHz}\right.$ in $\left.\mathrm{CDCl}_{3}\right): 1.08(9 \mathrm{H}, \mathrm{s}), 1.84$ $(3 \mathrm{H}, \mathrm{s}), 4.14(2 \mathrm{H}, \mathrm{dd}, J=4.9,1.5 \mathrm{~Hz}), 4.83(2 \mathrm{H}$, br s $), 4.98(1 \mathrm{H}$, br s $)$, $5.60(1 \mathrm{H}, \mathrm{dd}, J=15.9 \mathrm{~Hz}, 1.5 \mathrm{~Hz}), 6.04(1 \mathrm{H}, \mathrm{dt}, J=15.9,4.9 \mathrm{~Hz})$, $7.27-7.28(10 \mathrm{H}, \mathrm{m}) .[\alpha]_{D}^{23}=-123^{\circ}(c=1.01, \mathrm{EtOH})$. MS $m / z: 390\left(\mathrm{M}^{+}\right)$.

Oxidation of the Allyl Alcohol (23) A mixture of the allyl alcohol (23) $(260 \mathrm{mg}, 0.67 \mathrm{mmol})$ and active $\mathrm{MnO}_{2}(1.5 \mathrm{~g}, 17 \mathrm{mmol})$ in methylene chloride $(10 \mathrm{ml})$ was stirred at room temperature for $30 \mathrm{~min}$. The reaction mixture was filtered and the filtrate was concentrated to afford the aldehyde (24) $(217 \mathrm{mg}, 87 \%)$ as a pale yellow oil. IR $\left(\mathrm{CHCl}_{3}\right): 2220,1680 \mathrm{~cm}^{-1}$ ${ }^{1} \mathrm{H}-\mathrm{NMR}\left(90 \mathrm{MHz}\right.$ in $\left.\mathrm{CDCl}_{3}\right): 1.09(9 \mathrm{H}, \mathrm{s}), 1.85(3 \mathrm{H}, \mathrm{s}), 4.91(2 \mathrm{H}, \mathrm{brs})$, $5.05(1 \mathrm{H}$, br s $), 6.15(1 \mathrm{H}, \mathrm{dd}, J=15.8,7.1 \mathrm{~Hz}), 6.46(1 \mathrm{H}, \mathrm{d}, J=15.8 \mathrm{~Hz})$, $7.24-7.80(10 \mathrm{H}, \mathrm{m}), 9.48(1 \mathrm{H}, \mathrm{d}, J=7.1 \mathrm{~Hz}) . \mathrm{MS} m / z: 388\left(\mathrm{M}^{+}\right)$.

Methyl 8(R)-tert-Butyldiphenylsiloxy-9-methyl-deca-2 $(E), 4(E)$,9-trien6-ynoate (25) By use of the procedure as described for the preparation of the ester (22), the aldehyde (24) $(200 \mathrm{mg}, 0.52 \mathrm{mmol})$ gave the ester (25) $(192 \mathrm{mg}, 84 \%)$ as a colorless oil. IR $\left(\mathrm{CHCl}_{3}\right): 2400,1710 \mathrm{~cm}^{-1} \cdot{ }^{1} \mathrm{H}-\mathrm{NMR}$ $\left(90 \mathrm{MHz}\right.$ in $\left.\mathrm{CDCl}_{3}\right): 1.08(9 \mathrm{H}, \mathrm{s}), 1.85(3 \mathrm{H}$, br s) $, 3.75(3 \mathrm{H}, \mathrm{s}), 4.86(2 \mathrm{H}$, br s), $5.03(1 \mathrm{H}$, br s), $5.78(1 \mathrm{H}, \mathrm{d}, J=15.4 \mathrm{~Hz}), 5.92(1 \mathrm{H}, \mathrm{d}, J=15.2 \mathrm{~Hz})$, $6.33(1 \mathrm{H}, \mathrm{dd}, J=15.4,11.1 \mathrm{~Hz}), 7.20(1 \mathrm{H}, \mathrm{dd}, J=15.2,11.1 \mathrm{~Hz}), 7.26-7.81$ $(10 \mathrm{H}, \mathrm{m}) .[\alpha]_{\mathrm{D}}^{26}=-198.0^{\circ}(c=1.02, \mathrm{EtOH})$. HR-MS $\mathrm{m} / \mathrm{z}$ : Calcd for $\mathrm{C}_{28} \mathrm{H}_{32} \mathrm{O}_{3} \mathrm{Si}\left(\mathrm{M}^{+}\right): 444.2122$. Found: 444.2128 .

Methyl $6(R)$-tert-Butyldiphenylsiloxy-7-methyl-oct-2 $(E), 4(E)$,7-trienoate (27) A mixture of quinoline $(30 \mathrm{mg}, 0.24 \mathrm{mmol})$, Lindlar catalyst $(30 \mathrm{mg})$ and the methyl ester (22) $(100 \mathrm{mg}, 0.24 \mathrm{mmol})$ in ethyl acetate $(5 \mathrm{ml})$ was stirred at $0{ }^{\circ} \mathrm{C}$ under $\mathrm{H}_{2}$ for $2 \mathrm{~d}$ and filtered. The filtrate was concentrated to give a residue, which was submitted to flash chromatography in hexane-ether $(9: 1)$. Elution with the same solvent afforded the triene ester (27) $(87 \mathrm{mg}, 87 \%)$ as a colorless oil. IR $\left(\mathrm{CHCl}_{3}\right): 1705,1640 \mathrm{~cm}^{-1} \cdot{ }^{1} \mathrm{H}-\mathrm{NMR}$ $\left(400 \mathrm{MHz}\right.$ in $\left.\mathrm{CDCl}_{3}\right): 1.07(9 \mathrm{H}, \mathrm{s}), 1.65(3 \mathrm{H}, \mathrm{s}), 3.70(3 \mathrm{H}, \mathrm{s}), 4.83(1 \mathrm{H}$, brs), $4.95(\mathrm{lH}, \mathrm{d}, J=8.4 \mathrm{~Hz}), 5.09(1 \mathrm{H}, \mathrm{brs}), 5.69(1 \mathrm{H}, \mathrm{d}, J=15.4 \mathrm{~Hz})$, $5.71(1 \mathrm{H}, \mathrm{dd}, J=11.7,8.4 \mathrm{~Hz}), 5.91(1 \mathrm{H}, \mathrm{dd}, J=11.7,11.7 \mathrm{~Hz}), 7.04(1 \mathrm{H}$, $\mathrm{dd}, J=15.4,11.7 \mathrm{~Hz}), 7.29-7.66(10 \mathrm{H}, \mathrm{m}) .[\alpha]_{\mathrm{D}}^{17}=+30.1^{\circ}(c=1.01$, EtOH). HR-MS $m / z$ : Calcd for $\mathrm{C}_{26} \mathrm{H}_{32} \mathrm{O}_{3} \mathrm{Si}\left(\mathrm{M}^{+}\right)$: 420.2122. Found 420.2132 .

6(R)-tert-Butyldiphenylsiloxy-7-methyl-oct-2(E),4(E),7-trienal (28) By use of the procedure described for the preparation of $\mathbf{2 4}$ from $\mathbf{2 2}$, the cis-trans-diene ester (27) $(100 \mathrm{mg}, 0.24 \mathrm{mmol})$ gave the aldehyde (28) (79 mg, $85 \%$ overall yield) as a colorless oil. IR $\left(\mathrm{CHCl}_{3}\right): 1675,1630 \mathrm{~cm}^{-1}$. ${ }^{1} \mathrm{H}-\mathrm{NMR}\left(90 \mathrm{MHz}\right.$ in $\left.\mathrm{CDCl}_{3}\right): 1.07(9 \mathrm{H}, \mathrm{s}), 1.68(3 \mathrm{H}, \mathrm{s}), 4.89(1 \mathrm{H}, \mathrm{br} \mathrm{s})$, $4.91(1 \mathrm{H}, \mathrm{d}, J=10.8 \mathrm{~Hz}), 5.12(1 \mathrm{H}, \mathrm{brs}), 5.71-6.16(2 \mathrm{H}, \mathrm{m}), 6.74(1 \mathrm{H}$ $\mathrm{dd}, J=10.8,15.1 \mathrm{~Hz}), 7.24-7.71(11 \mathrm{H}, \mathrm{m}), 9.22(1 \mathrm{H}, \mathrm{d}, J=7.9 \mathrm{~Hz}) . \mathrm{MS}$ $m / z: 390\left(\mathrm{M}^{+}\right)$

Wadsworth-Emmons Reaction of the Aldehyde (28) By use of the method described for the preparation of 22, the aldehyde (28) (300 $\mathrm{mg}$, $0.77 \mathrm{mmol})$ gave the cis-trans-trans ester (29) $(295 \mathrm{mg}, 86 \%)$ as a colorless oil. IR $\left(\mathrm{CHCl}_{3}\right): 1700,1620 \mathrm{~cm}^{-1}$. ${ }^{1} \mathrm{H}-\mathrm{NMR}\left(400 \mathrm{MHz}\right.$ in $\left.\mathrm{CDCl}_{3}\right): 1.06$ $(9 \mathrm{H}, \mathrm{s}), 1.65(3 \mathrm{H}, \mathrm{s}), 3.73(3 \mathrm{H}, \mathrm{s}), 4.82(1 \mathrm{H}, \mathrm{br} \mathrm{s}), 4.88(1 \mathrm{H}, \mathrm{d}, J=8.8 \mathrm{~Hz})$, $5.07(1 \mathrm{H}$, br s), $5.59(1 \mathrm{H}, \mathrm{dd}, J=8.8,11.0 \mathrm{~Hz}), 5.80(1 \mathrm{H}, \mathrm{d}, J=15.4 \mathrm{~Hz})$, $5.90(1 \mathrm{H}, \mathrm{dd}, J=11.0,11.0 \mathrm{~Hz}), 6.10(1 \mathrm{H}, \mathrm{dd}, J=15.7,10.6 \mathrm{~Hz}), 6.17(1 \mathrm{H}$ dd $, J=15.7,11.0 \mathrm{~Hz}), 7.04(1 \mathrm{H}, \mathrm{dd}, J=15.4,10.6 \mathrm{~Hz}) .[\alpha]_{\mathrm{D}}^{17}=+5.5^{\circ}$ 
$\left(c=0.80\right.$, EtOH). HR-MS $m / z$ : Calcd for $\mathrm{C}_{28} \mathrm{H}_{34} \mathrm{O}_{3} \mathrm{Si}\left(\mathrm{M}^{+}\right)$: 446.2278 . Found: 446.2262 .

Epoxidation of the Ester (29) A mixture of the ester (29) $(320 \mathrm{mg}$ $0.72 \mathrm{mmol})$ and $m \mathrm{CPBA}(186 \mathrm{mg}, 1.1 \mathrm{mmol})$ in methylene chloride $(8 \mathrm{ml})$ was allowed to stand overnight at room temperature in the dark, and then $10 \%$ aqueous $\mathrm{NaHSO}_{3}$ and chloroform was added. The chloroform solution was washed with $3 \%$ aqueous $\mathrm{Na}_{2} \mathrm{CO}_{3}, 3 \%$ aqueous $\mathrm{NH}_{4} \mathrm{Cl}$ and water, and dried with $\mathrm{MgSO}_{4}$. Removal of the solvent gave a residue, which was submitted to flash chromatography in ether-hexane $(1: 9)$. Elution with the same solvent afforded the epoxide (30a) $(200 \mathrm{mg}, 60 \%)$ as the faster-running portion and the epoxide $(30 \mathrm{~b})(130 \mathrm{mg}, 39 \%)$ as the slower-running one.

Methyl $8(R)$-tert-Butyldiphenylsiloxy-9(S),10-epoxy-9-methyl-deca2(E),4(E),6(Z)-trienoate (30a): IR $\left(\mathrm{CHCl}_{3}\right): 1705,1620 \mathrm{~cm}^{-1}$. ${ }^{1} \mathrm{H}-\mathrm{NMR}$ $\left(90 \mathrm{MHz}\right.$ in $\left.\mathrm{CDCl}_{3}\right): 1.07(9 \mathrm{H}, \mathrm{s}), 1.39(3 \mathrm{H}, \mathrm{s}), 2.53(1 \mathrm{H}, \mathrm{d}, J=4.6 \mathrm{~Hz})$, $2.64(1 \mathrm{H}, \mathrm{d}, J=4.6 \mathrm{~Hz}), 3.75(3 \mathrm{H}, \mathrm{s}), 4.26(1 \mathrm{H}, \mathrm{d}, J=8.8 \mathrm{~Hz}), 5.60-6.09$ $(5 \mathrm{H}, \mathrm{m}), 6.97(1 \mathrm{H}, \mathrm{dd}, J=10.2,15.2 \mathrm{~Hz}), 7.25-7.73(10 \mathrm{H}, \mathrm{m})$ $[\alpha]_{D}^{15}=+16.1^{\circ}(c=1.60$, EtOH $)$. HR-MS $m / z$ : Calcd for $\mathrm{C}_{28} \mathrm{H}_{34} \mathrm{O}_{4} \mathrm{Si}$ $\left(\mathrm{M}^{+}\right)$: 462.2227. Found: 462.2202 .

Methyl $8(R)$-tert-Butyldiphenylsiloxy- $9(R), 10$-epoxy-9-methyl-deca2(E),4(E),6(Z)-trienoate (30b): IR $\left(\mathrm{CHCl}_{3}\right): 1705,1620 \mathrm{~cm}^{-1} \cdot{ }^{1} \mathrm{H}-\mathrm{NMR}$ $\left(90 \mathrm{MHz}\right.$ in $\left.\mathrm{CDCl}_{3}\right): 1.10(9 \mathrm{H}, \mathrm{s}), 1.36(3 \mathrm{H}, \mathrm{s}), 2.55(1 \mathrm{H}, \mathrm{d}, J=4.9 \mathrm{~Hz})$, $2.63(1 \mathrm{H}, \mathrm{d}, J=4.9 \mathrm{~Hz}), 3.73(3 \mathrm{H}, \mathrm{s}), 3.90(1 \mathrm{H}, \mathrm{d}, J=5.5 \mathrm{~Hz}), 5.60-6.35$ $(5 \mathrm{H}, \mathrm{m}), 7.10-7.74(11 \mathrm{H}, \mathrm{m}) .[\alpha]_{\mathrm{D}}^{15}=-28.9^{\circ}(c=1.26, \mathrm{EtOH})$. HR-MS $m / z$ : Calcd for $\mathrm{C}_{28} \mathrm{H}_{34} \mathrm{O}_{4} \mathrm{Si}\left(\mathrm{M}^{+}\right)$: 462.2227. Found: 462.2206 .

Methyl 9(S),10-Epoxy-8(R)-Hydroxy-9-methyl-deca-2 $(E), 4(E), 6(Z)$ trienoate (31) TBAF ( $3.12 \mathrm{ml}, 3 \mathrm{mmol}, 1 \mathrm{M}$ in THF) was added dropwise to a solution of $30 \mathrm{a}(200 \mathrm{mg}, 0.45 \mathrm{mmol})$ in dry THF $(5 \mathrm{ml})$ at $-10^{\circ} \mathrm{C}$, and the resulting mixture was stirred at room temperature for $1 \mathrm{~h}$ then diluted with ether $(50 \mathrm{ml})$. The ethereal solution was washed with brine, dried with $\mathrm{MgSO}_{4}$ and concentrated to give a residue, which was chromatographed on silica gel in hexane chloroform $(1: 4)$. Elution with the same solvent gave the alcohol $(31)(117 \mathrm{mg}, 68 \%)$ as a colorless oil. IR $\left(\mathrm{CHCl}_{3}\right): 3630,1700,1620 \mathrm{~cm}^{-1} .{ }^{1} \mathrm{H}-\mathrm{NMR}\left(90 \mathrm{MHz}\right.$ in $\left.\mathrm{CDCl}_{3}\right): 1.33$ $(3 \mathrm{H}, \mathrm{s}), 2.30(1 \mathrm{H}, \mathrm{brs}), 2.62(1 \mathrm{H}, \mathrm{d}, J=4.6 \mathrm{~Hz}), 2.96(1 \mathrm{H}, \mathrm{d}, J=4.6 \mathrm{~Hz})$, $3.75(3 \mathrm{H}, \mathrm{s}), 4.64(1 \mathrm{H}, \mathrm{d}, J=8.9 \mathrm{~Hz}), 5.40-6.93(6 \mathrm{H}, \mathrm{m})$. MS $m / z: 224$ $\left(\mathrm{M}^{+}\right)$.

Acylation of 31 with the Acid (16) By use of the method described for the preparation of 11, the cis-trans-trans hydroxy-ester (31) $(25 \mathrm{mg}, 0.11$ mmol) gave the ester (32) $(36 \mathrm{mg}, 40 \%)$ as an oil. IR $\left(\mathrm{CHCl}_{3}\right): 1745$, $1705,1620 \mathrm{~cm}^{-1} \cdot{ }^{1} \mathrm{H}-\mathrm{NMR}\left(400 \mathrm{MHz}\right.$ in $\left.\mathrm{CDCl}_{3}\right): 0.81(3 \mathrm{H}, \mathrm{t}, J=7.3 \mathrm{~Hz})$, $0.94(3 \mathrm{H}, \mathrm{d}, J=7.0 \mathrm{~Hz}), 1.08(9 \mathrm{H}, \mathrm{s}), 1.22(3 \mathrm{H}, \mathrm{s}), 1.45-1.75(3 \mathrm{H}, \mathrm{m})$, $2.50(1 \mathrm{H}, \mathrm{d}, J=4.8 \mathrm{~Hz}), 2.63(1 \mathrm{H}, \mathrm{d}, J=4.8 \mathrm{~Hz}), 3.77(3 \mathrm{H}, \mathrm{s}), 4.22(1 \mathrm{H}$, $\mathrm{d}, J=3.3 \mathrm{~Hz}), 5.26(1 \mathrm{H}, \mathrm{dd}, J=9.3,10.6 \mathrm{~Hz}), 5.47(1 \mathrm{H}, \mathrm{d}, J=9.3 \mathrm{~Hz}), 5.93$ $(1 \mathrm{H}, \mathrm{d}, J=15.4 \mathrm{~Hz}), 6.17(1 \mathrm{H}, \mathrm{dd}, J=10.6,11.3 \mathrm{~Hz}), 6.35(1 \mathrm{H}, \mathrm{dd}, J=14.6$, $11.4 \mathrm{~Hz}), 6.79(1 \mathrm{H}, \mathrm{dd}, J=14.6,11.3 \mathrm{~Hz}), 7.28-7.65(11 \mathrm{H}, \mathrm{m}) . \mathrm{HR}-\mathrm{MS}$ m/z: Calcd for $\mathrm{C}_{34} \mathrm{H}_{44} \mathrm{O}_{6} \mathrm{Si}\left(\mathrm{M}^{+}\right)$: 576.2908. Found: 576.2898 .

AF-Toxin IIa Methyl Ester (3b) By use of the procedure described for the preparation of 12, the ester (32) (24 mg, $0.041 \mathrm{mmol}$ ) gave AF-toxin IIa methyl ester (3b) $(9 \mathrm{mg}, 64 \%)$ as an oil. IR $\left(\mathrm{CHCl}_{3}\right): 3550,1735 \mathrm{~cm}^{-1}$. ${ }^{1} \mathrm{H}-\mathrm{NMR}\left(400 \mathrm{MHz}\right.$ in $\left.\mathrm{CDCl}_{3}\right): 0.87(3 \mathrm{H}, \mathrm{d}, J=7.0 \mathrm{~Hz}), 0.97(3 \mathrm{H}, \mathrm{t}$ $J=7.3 \mathrm{~Hz}), 1.36-1.40(2 \mathrm{H}, \mathrm{m}), 1.38(3 \mathrm{H}, \mathrm{s}), 1.83(1 \mathrm{H}, \mathrm{m}), 2.59(1 \mathrm{H}, \mathrm{d}$, $J=5.7 \mathrm{~Hz}), 2.62(1 \mathrm{H}, \mathrm{d}, J=4.8 \mathrm{~Hz}), 2.78(1 \mathrm{H}, \mathrm{d}, J=4.8 \mathrm{~Hz}), 3.76(3 \mathrm{H}, \mathrm{s})$, $4.19(1 \mathrm{H}, \mathrm{dd}, J=2.7,5.7 \mathrm{~Hz}), 5.52(1 \mathrm{H}, \mathrm{dd}, J=9.2,10.6 \mathrm{~Hz}), 5.81(1 \mathrm{H}, \mathrm{d}$ $J=9.2 \mathrm{~Hz}), 5.95(1 \mathrm{H}, \mathrm{d}, J=15.4 \mathrm{~Hz}), 6.33(1 \mathrm{H}, \mathrm{dd}, J=10.6,11.4 \mathrm{~Hz}), 6.41$ $(1 \mathrm{H}, \mathrm{dd}, J=11.4,15.0 \mathrm{~Hz}), 6.93(1 \mathrm{H}, \mathrm{dd}, J=11.4,15.0 \mathrm{~Hz}), 7.37(1 \mathrm{H}, \mathrm{dd}$, $J=11.4,15.4 \mathrm{~Hz})$, HR-MS $m / z$ : Calcd for $\mathrm{C}_{18} \mathrm{H}_{26} \mathrm{O}_{6}\left(\mathrm{M}^{+}\right): 338.1730$. Found: 338.1761 .

Acknowledgment This study was supported in part by Grants-in-Aid for Scientific Research (No. 61571007 and 63303013) from the Ministry of Education, Science and Culture of Japan. The authors are indebted to Professor T. Ueno (Pesticide Research Institute, Faculty of Agriculture, Kyoto University) for his help in biological testing of our synthetic samples.

\section{References}

1) S. Nakatsuka, K. Ueda, and T. Goto, Tetrahedron Lett., 27, 2753 (1986).

2) T. Nakashima, T. Ueno, and H. Fukami, Tetrahedron Lett., 23, 4469 (1982).

3) K. Ando, T. Yamada, Y. Takahashi, and M. Shibuya, Heterocycles, 29, 1023 (1989).

4) L. Crombie, M. A. Horsham, and S. R. M. Jarrett, Tetrahedron Lett., 30, 4299 (1989), L. Crombie and S. R. M. Jarrett, ibid., 30, 4303 (1989).

5) M. Laabassi and R. Gree, Tetrahedron Lett., 30, 6683 (1989).

6) H. Irie, K. Matsumoto, T. Kitagawa, Y. Zhang, T. Ueno, T. Nakashima, and H. Fukami, Chem. Pharm. Bull., 35, 2598 (1987), H. Irie, K. Matsumoto, T. Kitagawa, and Y. Zhang, ibid., 38, 1451 (1990).

7) In 1986, the stereochemistry of the 2-hydroxy-3-methylbutanoic acid moiety in AF-toxin II was confirmed by a synthesis of AF-toxin IIa methyl ester; S. Nakatsuka, K. Ueda, T. Goto, M. Yamamoto, S. Nishimura, and K. Kohmoto, Abstracts of Papers, 28th Symposium on the Chemistry of Natural Products, Sendai, Japan, 1986, p. 33.

8) M. Taniguchi, K. Koga, and S. Yamada, Chem. Pharm. Bull., 20, 1438 (1972).

9) A. Hassner and V. Alexanian, Tetrahedron Lett., 1978, 4475.

10) O. Mitsunobu, Synthesis, 1981, 1.

11) E. J. Corey and P. L. Fuchs, Tetrahedron Lett., 1972, 3769. 